\title{
From teaching physics to teaching children: Beginning teachers' learning from pupils
}

\section{Morag Findlay \& Tom G.K. Bryce \\ School of Education, University of Strathclyde, Glasgow UK}

Keywords: Initial teacher education, science teacher education, beginning teachers, pedagogical content knowledge, electricity

\begin{abstract}
This paper discusses the development of beginning physics teachers' pedagogical content knowledge (PCK) in the context of teaching basic electricity during a one-year Professional Graduate Diploma in Education course (PGDE) and beyond. This longitudinal study used repeated semi-structured interviews over a period of four-and-a-half years. The interview schedule followed a line of development through the secondary school electrical syllabus in Scotland. Fifteen student teachers were interviewed during the PGDE year. Six of them were followed up at the end of the Induction Year (their first year as a newly qualified teacher), and again two-and-a-half years later. Thematic analysis of the interviews showed that before the beginning teachers had taught any classes, their initial focus was on how to transform their own subject matter knowledge (SMK) about electricity into forms that were accessible to pupils. As the beginning teachers gained experience working with classes, they gave vivid descriptions of interacting with particular pupils when teaching electricity which showed the development of their pedagogical knowledge. This played a significant role in the teachers' change of focus from teaching physics to teaching children as they transformed their SMK into forms that were accessible to pupils and developed their general pedagogical knowledge.
\end{abstract}

\section{Introduction}

Currently, a number of governments around the world are concerned about pupil attainment in schools. One way to improve that attainment is to develop teachers' knowledge and skills (HMIE, 2005). In this context, a tactical approach is to consider the development of Shulman's (1987, p. 8) pedagogical content knowledge (PCK), that "special amalgam of content and pedagogy that is uniquely the province of teachers". PCK is therefore currently an active focus of investigation for researchers in science education, with attention particularly focused on early teacher development. This article examines the development of six beginning physics teachers' developing PCK in the context of teaching electricity.

\section{Wider context}

In Scotland, as in other countries, there is particular unease about the results of the Trends in International Mathematics and Science Study (TIMMS) (see Horne, Bejtka, \& Miller, 2008), and the Programme for International Student Assessment (PISA) (see Cooke \& Bejtka, 
2010), because Scotland is in the middle of these international rankings and not showing an improving performance. This unease arises despite consistently improving attainment in national school examinations (Scottish Government, 2010). Two approaches adopted in Scotland to improve the attainment of pupils were the introduction of the Assessment is for Learning (AifL) programme, Scottish Government (2005) and Bryce (2008); and the development and implementation of the Curriculum for Excellence (Curriculum Review Group, 2004; Learning and Teaching Scotland, 2010). Both of these approaches rely on more interactive teaching techniques and have required many teachers to adopt new approaches to teaching and learning. The Scottish Government explicitly intends to build the professional capacity of teachers to enable pupil attainment to improve. One of the implications of teaching in a more interactive way is that teachers can work more effectively if they develop their general pedagogical knowledge about how pupils learn.

Since its introduction by Shulman $(1986,1987)$,pedagogical content knowledge (PCK) has provided a framework to understand teacher education and development in general and science education in particular. Building the professional capacity of teachers can be carried out by encouraging teachers to reflect on their classroom practice. PCK offers a framework for teachers not only to reflect on what happens in the classroom but to identify their own development needs. The next section explores how it can be used as a theoretical framework to examine changes in beginning teachers' professional practice.

PCK has been used as a framework to understand science teacher education by GessNewsome \& Lederman (1999), Loughran, Mulhall \& Berry (2006), Bishop \& Denley (2007), Loughran, Mulhall and Berry (2008) and Nilsson (2008). It featured in recent reviews by Abell, Rogers, Hanuscin, Lee and Gagnon (2009) despite not being a fully developed theoretical framework as argued by Kind $(2009 \mathrm{~b})$ there being no agreed programmes of issues associated with it. Recently, Nilsson (2008), Kind (2009a), Nilsson \& van Driel (2010) and Nilsson \& van Driel (2011) have investigated the role of PCK in the development of student teachers of physics and other sciences in initial teacher education (ITE). They found that the transformation of student teachers' PCK is the result of the interplay of a complex range of factors. The student teachers learned as they began to transform their initial subject matter knowledge, contextual knowledge and pedagogical knowledge into PCK.

According to Arons (1997), physics is a conceptually difficult subject to learn and to teach. Some of the areas which have been identified as particularly difficult for secondary school pupils and university students, and which permeate the curriculum in both sectors, are electricity energy (Halloun \& Hestenes, 1985; Planinic, 2006) and forces (Halloun \& Hestenes, 1985; Mualem \& Eylon, 2010). These areas have also been found to be conceptually difficult for physics teachers, see for example Gunstone, Mulhall and McKittrick (2009), Halloun \& Hestenes (1985) and Singh and Rosengrant (2003). Other authors have found that PGDE students can also find it difficult to reconceptualise physics topics to teach them to pupils. Examples for this include: forces, Sharma \& Sharma (2007) and Millar (2008); electricity, Kücüközer \& Demirci (2008); and energy, Millar (2005). In the present study, electricity was selected to provide a context to investigate the development of beginning physics teachers' PCK also because it permeates the Scottish secondary physics curriculum.

This article reports on the development of beginning physics teachers' PCK with regard to the teaching of basic electricity during a one-year Professional Graduate Diploma in Education (PGDE), through the subsequent Induction Year and beyond, bridging the gap 
between studies which have concentrated on exploring the PCK of pre-service teachers (Sperandeo-Mineo, Fazio, \& Tarantino, 2006); or newly qualified teachers (Avraamidou \& Zembal-Saul, 2010; Lee, Brown, Luft, \& Roehrig, 2007) and other studies which have concentrated on more experienced teachers (Berry, Loughran, Smith, \& Lindsay, 2009; Henze, van Driel, \& Verloop, 2008; Verloop, van Driel, \& Meijer, 2001).

The reference to pre-service, newly qualified (Induction and years two and three of teaching) and more experienced teachers (three or more years of teaching) is consistent with several models of teacher development. Fuller \& Brown's (1975) discussion about pre-service teachers split teacher development into three phases: survival; task and impact. In the survival stage, teachers are concerned about even surviving as a teacher. In the task stage, the teachers' focus moves onto how they are functioning as a teacher; while in the final impact stage, teachers are concerned with the impact they have on their pupils' learning. Since then, this model has also been found to be a useful way to conceptualise the development of teachers during the Induction Year (the first paid post which a teacher holds for one year following qualification, equivalent to NQT in England) and beyond. Another approach to teacher development, suggested by Katz $(1972,2011)$ is similar. During the survival stage, often during the pre-service year, the teachers' focus is on themselves rather than the pupils. During the consolidation stage, which is often the Induction Year, teachers begin to focus on individual pupils. The renewal stage (years three and four) occurs when teachers have established well-organised and purposeful classrooms and continue to try new teaching techniques. When teachers become mature teachers, they take a more holistic view of teaching and their role as teachers. It is often at this stage that teachers begin to take on formal leadership roles in schools.

\section{Theoretical framework}

\section{PCK as a theoretical construct}

The major components of the PCK construct have been the subject of debate since Shulman (1986) introduced the construct as one of three components of teacher knowledge: content knowledge; pedagogical content knowledge and curricular knowledge. Indeed, Shulman in 1987 continued to develop his thinking and increased the number of components of teacher knowledge from three to seven: content knowledge; general pedagogical knowledge; curriculum knowledge; pedagogical content knowledge; knowledge of learners and their characteristics; knowledge of educational contexts; and knowledge of educational ends, purposes and values. Kind's $2009 \mathrm{~b}$ paper reviewed a number of different models and in particular reflected Gess-Newsome's (1999) distinction between integrative and transformative views of PCK. Kind also argued that the lack of agreement among researchers about how to conceptualise the component constructs within PCK means that the term is not yet a fully developed theoretical construct.

In her (1999, p10) discussion about categorising PCK, Gess-Newsome stated that PCK exists on a continuum between integrative and transformative poles and argued that the versions which most authors use lie between these extremes. The integrative model integrates the separate knowledge domains of PCK, but does not change them into something new in the way that the transformative model does. In fact, in the integrative model, "PCK does not exist as a domain of knowledge," Gess-Newsome (1999, p. 11), but teachers' professional knowledge is found at the intersection of the domains as teachers draw on the knowledge domains to manage a classroom situation. In contrast, in a transformative model, the 
relevant knowledge domain for teachers is PCK and the other knowledge domains remain in the background once they have been transformed.

The difference between the integrative and transformative models has implications for how researchers understand teachers' knowledge bases and therefore how they design their individual research. If PCK does not exist, then it cannot be observed and the individual knowledge bases must be considered separately. If it does exist as a knowledge base, then it can be observed and recorded and its development followed as teachers gain experience. According to Gess-Newsome (1999, p. 13), most research is positioned between these two extremes.

Shulman (1987) explicitly wrote about PCK being formed by the transformation of teachers' knowledge bases. Other authors who adopted a transformative approach to PCK include Grossman (1990) and Magnusson, Krajcik \& Borko (1999). Grossman (1990) introduced a tripartite division of PCK into general pedagogical knowledge (GPK), subject matter knowledge (SMK) and knowledge of context (CxK), which was also discussed by (Magnusson, et al., 1999, p. 98, Figure 1). Although Grossman's initial work was with English teachers, the tripartite division has subsequently been used by other researchers in science education, including Gess-Newsome (1999), van Driel, Beijaard, \& Verloop (2001), Henze, van Driel, \& Verloop (2007b), Nilsson (2008) and van Driel (2010), which suggests that the tripartite division of PCK is a productive approach for some researchers.

A different transformative model was developed by Magnusson, Krajcik, \& Borko (1999, p. 99) who argued that PCK has five components. The first component which they included was orientation towards science teaching which then affects and is affected by knowledge and beliefs about: science curricula; students' understanding of science; instructional strategies; and assessment of scientific literacy. Magnusson et al. argued that the most important component of PCK was a teacher's orientation towards science teaching because it would influence the ways in which they would teach.

An integrative approach to PCK has been adopted by Cochran, DeRuiter, \& King (1993) who adopted an explicitly integrative approach to PCK and coined the term Pedagogical Content Knowing (PCKg) to capture the dynamic and developing nature of PCK. The authors' stance is to use a variant of Grossman's tripartite division of PCK, while explicitly considering other components of PCK as identified by Shulman (1987). This is similar to the approach taken by Bishop \& Denley (2007) to use the components of PCK as a way to enable teachers to understand its dynamic nature and to use these ideas to develop their practice. This places these authors towards the transformative end of Gess-Newsome's $(1999$, p. 14) continuum while recognising that the individual components of PCK can be recognised separately (Magnusson et al., 1999).

\section{SMK for Teaching Electricity}

The focus of this paper is on the beginning physics teachers' developing SMK within the context of teaching about electricity. Around the same time as Driver, Guesne and Tiberghien (1985) were investigating pupils' conceptual difficulties across a range of science topics, Duit, Jung, \& von Rhöneck (1985) edited the book of a conference which discussed pupils' difficulties learning electricity. This was one of the first books to make research about teaching electricity and the difficulties that pupils can have learning about electricity more widely available. More than a decade later, Duit and von Rhöneck (1998) reported similar findings about the difficulties pupils had learning about electricity. In between, 
Picciarelli, Di Gennaro, Stella and Conte (1991a, 1991b) investigated university students' understanding of basic electricity and concluded that there were gaps and misunderstandings in their knowledge. More recently Mulhall, McKittrick and Gunstone (2001, p. 580) have suggested a number of reasons why pupils find it difficult to learn about electricity:

... there are not even the beginnings of any form of justified consensus about the range and nature of models/analogies/metaphors that might be appropriate for the teaching of electricity at any given level or at different levels.

They went on to argue that the basic concepts of electricity are not clearly defined in many textbooks. They also argued that electricity is a difficult topic for pupils to learn because the content is very abstract, and consists entirely of models. The abstract nature of understanding electricity means that it is a difficult topic for teachers to teach. These difficulties in understanding basic direct current resistive circuits prompted Engelhardt and Beichner (2004) to develop a diagnostic test for the misconceptions held by school and university students about basic direct current resistive circuits, even after teaching.

Another reason why pupils may find it difficult to understand electricity is that some of their teachers may have misconceptions about basic electrical concepts and may therefore confuse pupils. McDermott, Heron, Shaffer and Stetzer (2006) have shown that teachers across the age range can have difficulty understanding and therefore teaching electricity to pupils. Other studies have documented teachers' difficulties in specific sectors: in primary schools Heller and Finley (1992)and in middle schools Pardhan and Bano (2001). Many authors have also discussed the difficulties that teachers have with electricity in the secondary school, including Cohen, Eylon and Ganiel (1983), Stocklmayer \& Treagust (1996), Borges and Gilbert (1999), Kücüközer \& Demirci (2008) and Gunstone, Mulhall and McKittrick (2009). These studies have all shown that teachers in a number of countries hold similar misconceptions to one another and to pupils. Therefore, electricity was selected here as a suitably challenging context to examine the development of beginning teachers' PCK.

\section{Contextual knowledge}

Combining Grossman's (1990) tripartite division of PCK with Shulman's (1987) knowledge bases for teachers suggests that Grossman's contextual knowledge $(\mathrm{CxK})$ consists of curriculum knowledge, which overlaps with SMK, and knowledge of educational contexts, such as the community, pupils, school and local authority. A similar combination of Grossman and Shulman (1987) suggests that (general) pedagogical knowledge (GPK) consists of knowledge of learners and their characteristics and knowledge of educational ends, purposes and values. Grossman suggested that general pedagogical knowledge consists of knowledge of classroom management, instructional principles, learners and learning and educational aims. The knowledge base for GPK will be discussed in the next section.

The Scottish Education system, described in Bryce \& Humes (2008), provides the overall context for the development of the teachers in this study. Within this national context, student teachers on a PGDE course typically have placements in two schools, allowing them to compare them and to begin to discover differences between schools and pupils.

The other main influences on the contextual knowledge of Scottish teachers are the school curricula for different levels. Since this study began, the curricular documents for the first 
two or three years of secondary school, the 5-14 Guidelines, Scottish Executive (2000), have been supplemented by the introduction of the Assessment is for Learning (AifL) programme, Learning and Teaching Scotland (2002), and superseded by the introduction of the Curriculum for Excellence (CfE), Learning and Teaching Scotland (2008), currently for ages 3 - 15 (Learning and Teaching Scotland, 2010). The current examination syllabi for pupils in the Fourth, Fifth and Sixth Years of secondary education are available from the Scottish Qualifications Authority (SQA) website (SQA, 2004a, 2004b, 2004c, 2004d, 2004e).

A recent change in the Dutch science curriculum to focus more on the use and production of models in science teaching has allowed the publication of a number of papers about the changes in experienced teachers' PCK. Henze, van Driel, \& Verloop (2007a) discussed the impact on science teachers of teaching about models and modelling in science. Their conclusion was that teachers developed different approaches to teaching the same material depending on their view of modelling in science. This conclusion was supported by later work published by the same authors (Henze, et al., 2008).

\section{General Pedagogical Knowledge}

For pre-service teachers, the two main sources of their general pedagogical knowledge (GPK) are probably their ITE courses and their school-based interactions with pupils and colleagues. During this experience, most pre-service teachers are at the survival stage and concerned to develop their GPK so that they can cope with the normal rigours of the classroom. Most research on science teachers' PCK tends to focus on PCK itself or SMK rather than GPK. However, Henze, et al. (2007b) investigated the impact of the introduction of a new subject on the PCK, SMK and GPK of experienced Dutch science teachers. They found evidence of two different kinds of PCK. Some of the teachers still adopted a teacher-centred view of teaching, while others adopted more constructivist and pupil-centred approaches. For both groups, the type of PCK developed was consistent with the teachers' GPK.

A different approach to exploring the development of biology teachers was used by GessNewsome et al. (2011) who followed biology teachers implementing a new biology curriculum with a high level of professional support. The researchers measured various aspects of the teachers' PCK and found that only GPK impacted significantly on the teachers' practice, although it was academic content knowledge (ACK - assumed to be equivalent to SMK) which had an impact on pupils' achievement.

\section{Relationship between the components of PCK}

Teaching is a complex undertaking, which relies on teachers having a wide range of knowledge and skills and being able to build relationships with learners to allow the learners to learn. PCK and its associated knowledge bases provide science education researchers with a framework to understand the development of teaching, albeit there are still debates about the status of the framework. One of the issues with using PCK as a framework is that researchers interpret it in different ways along Gess-Newsome's (1999) integrative transformative continuum. At the heart of the debate is whether PCK should be understood as teachers drawing on the separate knowledge bases while teaching or whether the knowledge bases are combined into teachers' professional knowledge: PCK. This debate is complicated by the fact that when they are in the classroom, teachers' decisions are influenced by several factors, not least the pupils, as they use knowledge bases in complex 
and inter-connected ways which are difficult to untangle. There will also be variations in what they each are able to try to explain from time to time. These have implications for a researcher's methodology.

\section{Research questions}

The general aim of the research was to investigate the development of six beginning physics PCK within the context of teaching about electricity during their PGDE year and over the early stage, Fuller \& Brown (1975), or renewal stage, Katz (1972, 2011), of learning to teach. As a result, the research questions were focused more in investigating SMK related to teaching electricity rather than CxK or GPK.

More specifically:

How did the beginning teachers' subject matter knowledge about teaching electricity change and develop over the first few years of teaching?

Over the same period, how did their general pedagogical knowledge and curricular knowledge change and develop?

\section{Methodology}

The study reported here was carried out by the lead author while working as a tutor in a Scottish Teacher Education Institution (TEI) as part of a wider study following the progress of PGDE student teachers of physics. This longitudinal study lasted for four-and-a half years and followed the early development of the teachers at the beginning and end of their PGDE year; at the end of the following Induction Year and then again after a further two-and-a-half years of teaching. The study design used repeated, semi-structured. Table 1 shows when the four interviews were carried out. Table 2 shows the timing of the interviews with the six teachers. Teachers 1, 2 and 5 participated in all the interviews. Teacher 4 did not take part in Interview 2 and Teachers 3 and 6 did not participate in the final interview. 
Table 1 Timeline for the repeated interviews with the beginning teachers of physics.

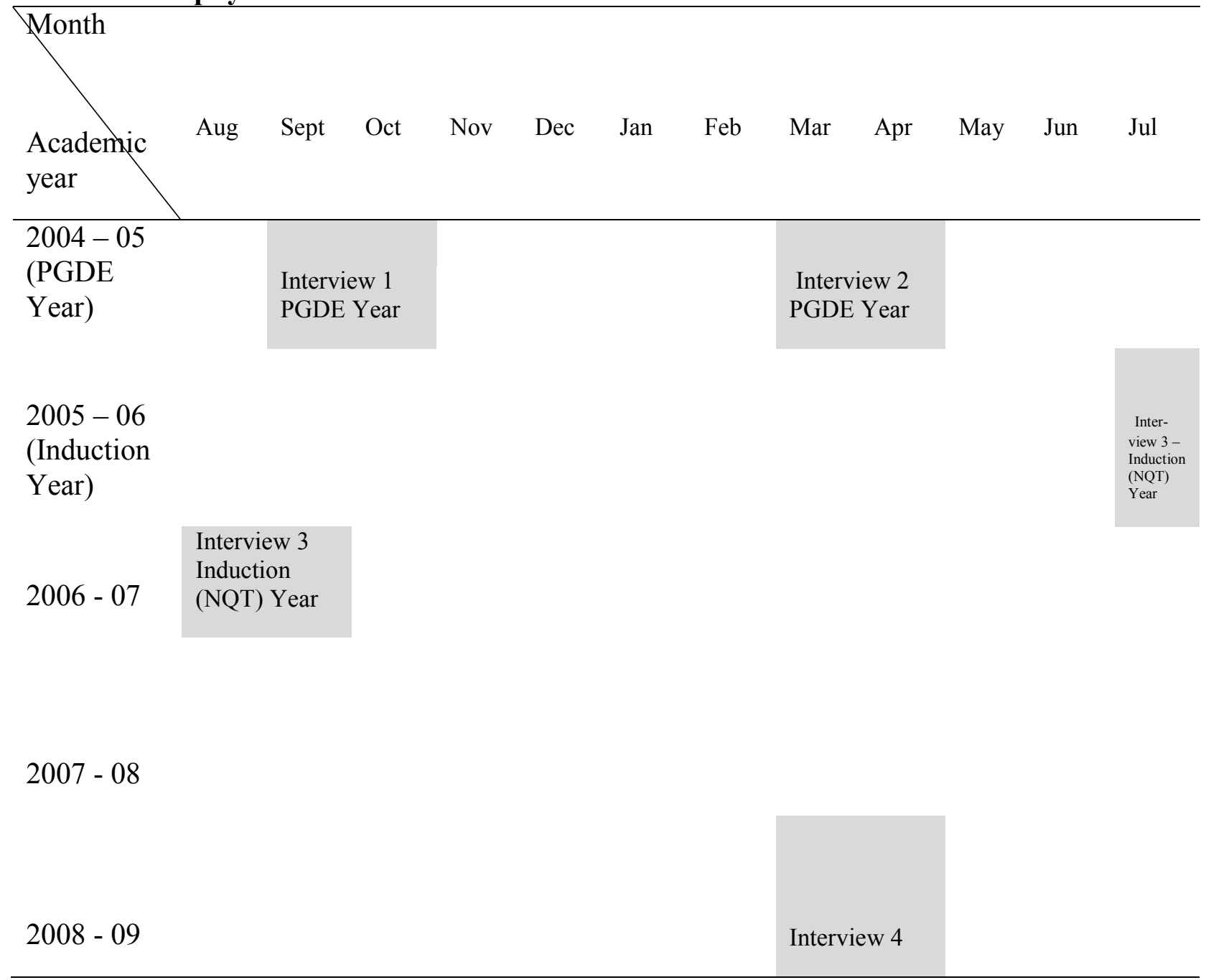

Table 2 Timing of interviews with Teachers $1-6$

\begin{tabular}{ccccc}
\hline Teacher & $\begin{array}{c}\text { Interview 1 } \\
\text { (Beginning } \\
\text { of PGDE } \\
\text { Year) }\end{array}$ & $\begin{array}{c}\text { Interview 2 } \\
\text { (End of } \\
\text { PGDE Year) }\end{array}$ & $\begin{array}{c}\text { Interview 3 } \\
\text { (End of } \\
\text { Induction } \\
\text { (NQT) } \\
\text { Year) }\end{array}$ & $\begin{array}{c}\text { Interview 4 } \\
\text { (Post- } \\
\text { Induction) }\end{array}$ \\
\hline 1 & $\checkmark$ & $\checkmark$ & $\checkmark$ & $\checkmark$ \\
2 & $\checkmark$ & $\checkmark$ & $\checkmark$ & $\checkmark$ \\
3 & $\checkmark$ & $\checkmark$ & $\checkmark$ & - \\
4 & $\checkmark$ & $\checkmark$ & - & $\checkmark$ \\
5 & $\checkmark$ & $\checkmark$ & $\checkmark$ & $\checkmark$
\end{tabular}


The decision about the method used to gather data considered the ethical implications for a teacher educator carrying out research with student teachers who would also be assessed by her. This precluded direct observation as a research method and suggested that a less direct method such as interviewing would be less intrusive on the tutor-student teacher relationship. Another consideration was the need to gather thick data to track any changes in the beginning teachers' approaches to teaching electricity. This suggested that a qualitative approach would provide the type of data required.

Within a constructivist paradigm, a qualitative and interpretative approach, Merriam \& Associates (2002), using a case study methodology, Merriam (1998) and Yin (2009), offered a method to collect detailed information from the beginning teachers about their approaches to teaching electricity. The case study was bounded in time rather than location because the teachers all had experience teaching in at least three different schools. Within this case study approach, repeated semi-structured interviews were used to gather data, leading to "thick" descriptions, Geertz (1973, pp. 3-30), of each case and comparisons to be made across time.

To answer the research questions about the development of the teachers' subject-specific PCK about teaching electricity, a repeated semi-structured interview schedule was developed (see Appendix 1) and subsequently administered by the first author four times to the beginning teachers over a period of four-and-a-half years. The interview schedule followed a possible line of development through the Scottish secondary school electrical syllabus for pupils of ages 12 to 16 using the (then applicable) 5 - 14 Environmental Studies Guidelines, Scottish Executive (2000), and the Standard Grade Physics Arrangements Document, SQA (2004e), as guides. The interview schedule contained circuit diagrams and interview questions about them. The beginning teachers were given copies of the circuit diagrams but not the questions. The interviews started by asking about the teaching of basic, qualitative current electricity in series and parallel circuits in the first and second years of secondary school. The next stage was to ask about teaching the same topics to examination classes in third and fourth year, followed up by a qualitative discussion about voltage divider circuits. The beginning teachers were also asked if they had any general points they wished to make about teaching electricity. The interviews were audio recorded and transcribed using a simple transcription system Edwards (2006). The transcripts were initially analysed using an analytical framework derived from Shulman's (1987: p. 8) version of PCK using SMK, general pedagogical knowledge and contextual knowledge as the main organisers see Table 3. The concepts in Table 3 were derived from the six components which Shulman (1987, p. 8 ) suggested were part of PCK. When teaching about electricity, teachers may use large numbers of analogies and metaphors, Harrison (2008) and Hart (2008), so analogies and metaphors were included in the list of concepts. Similarly, reflection has been identified as an important component of teacher development, McNally \& Blake (2010), and was therefore included in the list of concepts. The second column in Table 3 shows some indicative codes which were used to identify the associated concepts. 


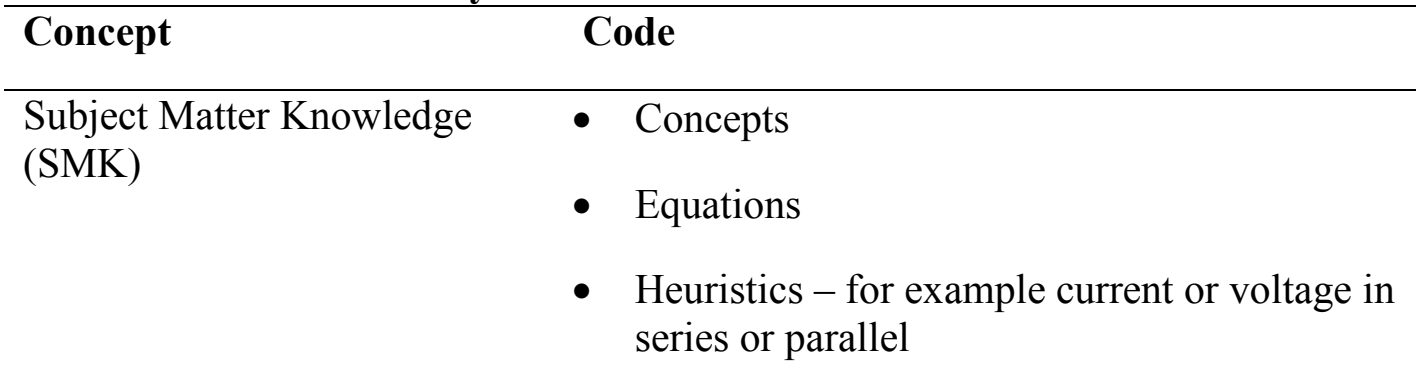

SMK - Analogies and metaphors

General Pedagogical Knowledge (GPK)

GPK - Learners

Contextual Knowledge $(\mathrm{CxK})$

CxK - Curricular Knowledge

CxK - Values

CxK - Reflection
- Analogies for physical concepts, for example an electric current is like a flow of water

- Metaphors, for example a flow of current

- Approaches taken to learning and teaching

- Classroom organisation and management

- Information about:

○ a particular class

○ pupils

- Wider information about the school

- Other school years or courses

- Content of other courses

- Evidence of values

- Statements indicating reflection:

○ "I think"

○ "when I was a pupil"

- Comparing pupils or classes

- Success or otherwise of different approaches 
Table 4 Relationship between concepts and indicative emergent codes for PCK, concentrating on the teachers' Subject Matter Knowledge.

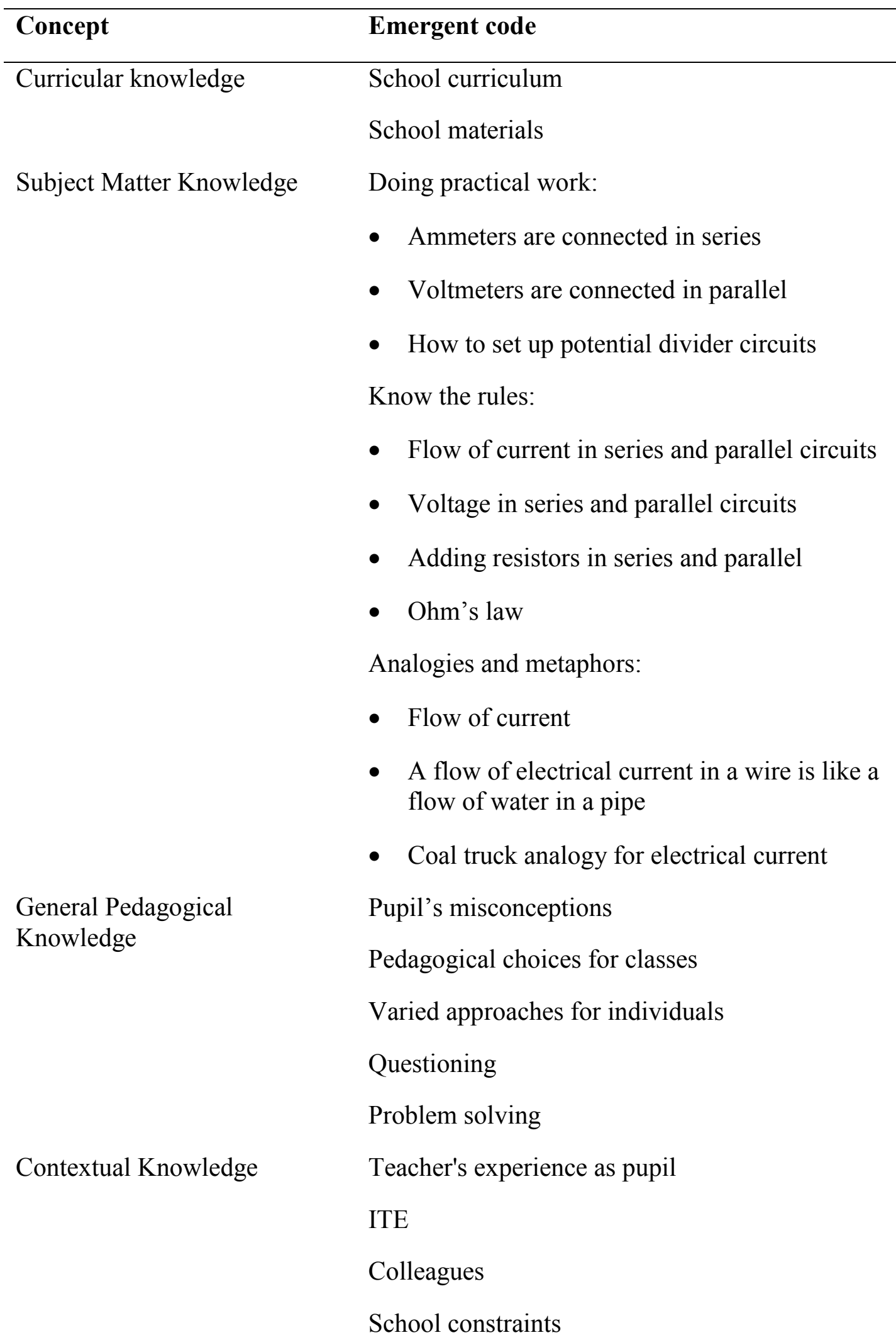


Role of practical work

Ethos

Reflection

Learners

Pupils as learners

Reflection

Teachers learning from pupils

Over the course of the initial thematic analysis, Boyatzis (1998), further more specific categories emerged from the data, see Table 4, to reflect comments made by the beginning teachers. These emergent categories were used to re-analyse the data in terms of the themes uncovered in the interview transcripts. The use of the initial analytical framework and the emergent thematic analysis allowed the development of a thick description of the development of the main components of the beginning teachers' PCK over time.

To check the validity of the coding, a colleague independently coded the data and only data where there was inter-coder agreement were used as the basis to build the case studies of the six beginning teachers. Once both researchers had independently coded the transcripts, paragraph by paragraph comparison of the coding gave of inter-rater agreement of $86 \%$. During both stages of the coding process, both researchers found that there was overlap between the concepts, which was taken to be evidence of the transformation of the beginning teachers' separate knowledge bases into PCK (Nilsson, 2008).

Fifteen of the 29 students in one PGDE cohort took part in two interviews during their PGDE year. Six were followed up a year later at the end of the Induction Year and again nearly three years later. During the course of this research, all of the teachers spent time teaching in at least three schools. All of the teachers had placements in two schools and the beginning teachers were placed in a third school for their Induction Year. The six teachers who had participated in Interview 3 had different experiences after the Induction Year: Teacher 1 worked as a supply teacher in different schools until he had gained a permanent post by the time of Interview 4; Teacher 2 remained in his Induction School until at least the time of Interview 4; Teacher 4 had recently moved to a second post-Induction School at the time of Interview 4; Teacher 5 was teaching in a Residential School at the time of Interview 4. Teachers 3 and 6 participated in Interview 3 only. Teacher 3 had returned to work in industry at the time of Interview 4 and Teacher 6 was still teaching, but was employed as a Mathematics teacher. This information and the timing of the interviews are summarised in Tables 1 and 2.

\section{Findings}

Introduction

One of the issues which arose when coding the interview transcripts was that many statements showed the complex interaction between the components of PCK. For example the first quotation in the SMK development section [T1.1.3b] below, showed Teacher 1 reflecting on his own electrical SMK; his GPK awareness that his SMK needed to be changed 
into a form which the pupils could understand; his additional GPK awareness that pupils learn in different ways and an approach which might be understood by one pupil might not be understood by another. At this initial stage in his development as a teacher, he planned to find teaching approaches which would allow some pupils to learn the concept for the first time and other pupils to consolidate their knowledge without becoming bored. Teacher 1 was aware of the potentially daunting nature of learning to teach only a few weeks from the start of the PGDE course and before any significant experience in a school as a teacher.

When analysing the data from any of the teachers, one of the conclusions drawn was that all of the teachers were reporting different approaches to teaching. These differences arose for two reasons. The first is that all the teachers brought differing experiences to teaching because they had different first degrees and had worked in different organisations before they started teaching. The second reason is that the teachers were different people with different personalities. Both sets of reasons inevitably affected how the teachers approached classroom teaching and reflecting on it. The approach taken to report the findings is to discuss some of the general findings about SMK, GPK and CxK and then to use a case studies about each of the teachers to highlight the similarities and differences between them.

\section{Common Experiences}

Analysis of the interview transcripts showed that the teachers had similar experiences in developing aspects of their SMK, GPK and CxK. All of these teachers showed an awareness that they needed to develop their SMK into a form which was suitable for use with pupils. All of the teachers showed evidence that their GPK was developing as they reflected on pedagogical approaches which they had tried and adapted. None of the teachers made specific references to curricular documents because the interview schedule was designed to follow a possible pathway through the electrical syllabus. However, the teachers did make reference to their $\mathrm{CxK}$ about pupils and classes.

\section{Subject Matter Knowledge (SMK) transformation}

This section considers the teachers' own SMK about teaching electricity as expressed in the interview transcripts and examines how it was transformed as they interacted with pupils. The section then considers their wider SMK transformation about teaching electricity. At the start of the PGDE course, the beginning physics teachers expressed an awareness of their own SMK but were conscious that this was not in a suitable form for use with pupils.

When the first interview with the beginning teachers was carried out at the start of their PGDE year, none of the beginning teachers had spent much time on placement. Some of them were interviewed before a two-week induction placement and some after the induction placement. Nevertheless, all the beginning teachers expressed a level of concern about how to transform their own university-level understandings of electricity into a format which would be suitable for pupils:

This is where you know it's interesting because I understand it, but how do I explain it in a logical fashion that the kids'll understand because we know that they'll... learn in different ways. So it's something you're going to have to try because as we've talked before some kid might look at that and go, oh yeah I understand it and other children, their learning styles are different, so you have to try and attack it at different set of viewpoints to try to get the information across and hopefully [help to] consolidate ones who understood it earlier as well.

[T1.1.3b] 
Teacher 1 was also aware of the need to develop his general pedagogical knowledge about learning styles and how to adapt teaching approaches for different pupils, while at the same time ensuring that the pupils who had already grasped the concept received positive reinforcement rather than became bored. Using a teaching approach for more than one purpose can be seen as an important component of GPK.

There are examples of the other teachers discussing the need to develop their SMK into a form which the pupils could understand. Some of these illustrate the overlap between SMK and GPK and implicitly CxK. For example, Teacher 2 changed and adapted his use of analogies depending on the age, ability and syllabus of the class and pupils that he was working with. Teacher 3 took a different approach and used mathematics as a route to understanding rather than using analogies. Teacher 4 developed her own SMK and concentrated specifically on the information which the pupils needed to know. Teacher 5's pedagogy in mainstream schools depended heavily on interactive questioning with classes. This approach had to be adapted when he started working in Residential Schools. Teacher 6 adopted the approach that the pupils had to know the rules which they would apply in particular situations, but humanised this by showing them the sort of mistakes which he had made as a pupil.

All of the teachers approached adapting their SMK and learning to teach in different ways. As well as adapting their SMK, one of the other common approaches was that they took a reflective stance about their own learning. For all six teachers, their reflection was informed by their learning from their pupils.

\section{General Pedagogical Knowledge (GPK) transformation}

The second component of PCK to be considered is GPK. Teachers develop their GPK as they draw on their ITE experience and interact with colleagues and pupils. One of the main ways in which all teachers develop their GPK is by reflecting on the interaction between their theoretical knowledge and classroom experience, which is a requirement of the General Teaching Council for Scotland (2006a, 2006b).

In one sense, reflection permeated the interviews because these beginning teachers were given an extended opportunity to reflect on how they had taught electricity on three or four separate occasions. More specifically, the teachers also explicitly commented on what they had learned from pupils throughout the interviews, although some more than others. This aspect is drawn out in the case studies.

During the thematic analysis of the interview schedules, the two aspects of GPK which were mentioned most frequently by the teachers were the role of problem solving and practical work in teaching and learning physics.

The six beginning teachers discussed in this paper used a number of approaches to teaching electricity. They transformed their teaching approaches as they interacted with and learned from their pupils. All of the teachers used a variety of approaches, but referred to some approaches more than others. These approaches favoured by each teacher are discussed in the case studies below. The most common teaching approaches were carrying out practical work; and problem solving by knowing and applying the relevant electrical circuit rules.

Another use some of the beginning teachers identified for practical work was to solve written circuit problems. On some occasions, when some of the pupils were unable to solve a 
written problem, one approach was use the circuit diagram to build the circuit and then to use the pupils' measurements to help them to understand the original written problem.

\section{I would certainly like them to try and predict before we started on an experiment.

Basically we used the previous experiments and might stick in multi-meters at various points in the circuit.

[T3.3.4a]

If they can't get it, to look at it - I would go and get them to get equipment and set it up.

[T4.3.4a]

This suggests that some of these teachers had learned from their pupils to approach some problem solving situations practically rather than theoretically.

The teachers highlighted a number of different approaches to solving these problems, ranging from constant reinforcement of the basic concepts the pupils could use to solve the problems they met to using analogies as a possible approach to understanding. The teachers used revision and repetition as another approach to remind some pupils of what they already knew.

Problem solving with pupils drew on a number of skills which the teachers had developed, including questioning. In addition, to solve problems the pupils had to draw on the rules for electrical circuits they had previously learned and which are included in Table 4. Problem solving also drew on the pupils' knowledge about circuit components. All the teachers used heuristics based on their own SMK and their learning from the pupils.

To solve written or drawn circuit problems, the teachers suggested a range of techniques. These ranged from the apparently contradictory instruction to consider the big picture or to focus on a particular part of the circuit. Linked to this local focus, the pupils were encouraged to write down all the information they had about part of a circuit or component, and if still unable to proceed, to use a "common sense" approach and calculate anything they could work out from that information as a possible way forward. Another approach some of these teachers suggested was to redraw the circuit diagrams in a more familiar format or to simplify parts of the circuit in the hope that this would enable pupils to progress. The final approach, if all of the previous approaches failed, was to tell pupils to build the circuit and investigate the problem practically.

One of the difficulties teachers may have when teaching about electrical circuits is how to teach pupils to think about the circuits. To solve some problems, the pupils have to consider the circuit as a whole, whereas to solve other problems the pupils have to focus on a particular component or branch of the circuit. Some pupils find swapping between the different ways of thinking about the circuit difficult. All of the approaches described in the previous paragraph illustrated the teachers learning how to teach by interacting with and learning from their pupils. They increased their repertoire of teaching approaches and adapted them to different pupils as appropriate.

\section{Contextual Knowledge Transformation}

Although the teachers had all taught a range of classes and would have been familiar with the content of the curriculum, there was little explicit mention of curricular documents in their interviews. (At the time of the study, the Scottish educational system had two parallel sets of examinations at the end of compulsory secondary education. Standard Grade 
examinations were originally introduced in the 1980s and were examined at three levels. The new National Qualifications at Access 3, Intermediate 1 and Intermediate 2 were introduced in 1998 and corresponded to the three levels of the Standard Grade examinations. Typically, Standard Grade, Access and Intermediate courses were studied by pupils in the age range $14-15$ although the details varied between schools.) Table 5 summarises which classes the teachers had taught. All of the teachers had taught First and Second Year General Science classes and Standard Grade Physics. The National Qualifications Access 3 and Intermediate 1 and 2 Physics (which are broadly equivalent to the different levels of Standard Grade) were being taught in schools, although these teachers mainly taught at Intermediate 2 level. Only half of the teachers were teaching a Higher Physics class. Teachers 2 and 4 taught in smaller rural schools and therefore had the opportunity to take Higher Physics classes. Teacher 1 had taught Higher Physics but was not doing so at the time of Interview 4. The smaller number of teachers teaching Higher and Advanced Higher Physics classes is probably explained by the reluctance of Principal Teachers to allow less experienced teachers to take these classes.

Table 5 Level of classes and ages of pupils taught.

\begin{tabular}{|c|c|c|c|c|}
\hline Class & $\begin{array}{l}\text { First and } \\
\text { Second } \\
\text { Year }\end{array}$ & $\begin{array}{c}\text { Standard } \\
\text { Grade or } \\
\text { National } \\
\text { Qualifications }\end{array}$ & Higher & $\begin{array}{c}\text { Advanced } \\
\text { Higher }\end{array}$ \\
\hline Age & $12-14$ & $14-16$ & $16-17$ & $17-18$ \\
\hline 1 & $\checkmark$ & $\checkmark$ & $\checkmark$ & $x$ \\
\hline 2 & $\checkmark$ & $\checkmark$ & $\checkmark$ & $\checkmark$ \\
\hline 3 & $\checkmark$ & $\checkmark$ & $x$ & $x$ \\
\hline 4 & $\checkmark$ & $\checkmark$ & $\checkmark$ & $x$ \\
\hline 5 & $\checkmark$ & $\checkmark$ & $x$ & $x$ \\
\hline 6 & $\checkmark$ & $\checkmark$ & $x$ & $x$ \\
\hline
\end{tabular}

Overall in the interviews, there were no explicit references to specific curricular or arrangements documents. The teachers' curricular knowledge tended to be implicit and embedded in their references to teaching particular pupils or classes rather than reference to the national examinations arrangements documents. The teachers were more likely to refer to "my pupils" who were working at a particular level:

... another thing I've been showing my pupils...

... with my Intermediate 1 class...

My first year class were coming in at level 3-they've done science courses at Level $E$ and Level F. 
The teachers started referring to "my pupils" very early in their teaching career during Interview 2 which was conducted towards the end of their PGDE year and was the first interview which probed their teaching experience. They continued to talk about "my pupils" or "my classes" in the subsequent interviews.

\section{Case Studies}

The case studies about each of the teachers are used to illustrate some of the similarities and differences in their development as beginning teachers. They also show something of the impact of the teachers' different approaches and contexts as they continued to learn how to teach. The case studies leave a strong impression that the teachers are learning about some aspects of how to teach from the pupils.

\section{Case Study 1 - The Role of Practical Work}

Teacher 1 was a mature entrant to teaching with a B.Sc. in Mechanical Engineering and who completed the PGDE Year qualified to teach Physics in schools. He had been placed in two state schools during the PGDE year and a third in the Induction Year. At the time of Interview 4, he had been employed as a supply teacher in a number of schools and had recently obtained a permanent post.

As discussed in the earlier section about developing SMK, Teacher 1 was the teacher who talked most about the need to change his SMK into a form which was relevant to the pupils he was teaching and linked this to the development of his GPK. At the earliest stage of his teaching career, he showed that he valued the development of pupils as learners and was already demonstrating a task-orientated approach to teaching. This was also shown by the rationale which he gave for using practical work in science.

Practical work permeated the practice of all of the beginning physics teachers and was at the core of their practice, although for most this was implicit in the interviews. Teacher 1 gave the most detailed answers about the role of practical work as a way to allow the pupils to begin to develop their own ideas with guidance from the teacher rather than simply telling the pupils the answer.

You don't want to remove yourself too much. You say to them: There's the equipment. You know how to look after the equipment and set it up and let them do it for themselves ... It's dead easy to say, Right this is what's happening, and occasionally you feel yourself wanting to say, this is how it is instead of letting them find it.

[T1.3.3a]

Teacher 1 was reflecting on the balance between giving the pupils too little or too much autonomy in their learning. His values as a teacher were reflected in the way in which he trained the pupils to use the equipment and then trusted them to use it correctly. However, Teacher 1 also felt pressurised as a member of staff to keep up the pace of learning and was concerned to resist the pressure to simply tell the pupils the answers to save time. This demonstrates the interactions between his understanding of the learners; the values he espoused in his teaching; and his GPK. 
Teacher 1's approach to practical work was also an example of his growing curricular knowledge. At the time of the third interview, the Scottish Government was planning to introduce a new curricular approach: the Curriculum for Excellence (CfE), Curriculum Review Group (2004) in three years' time. CfE was used to justify Teacher 1's approach to the role of practical work in learning:

You tell them: There's the equipment. You know how to look after the equipment and set it up and then let them do it for themselves: the whole Curriculum for Excellence thing.

Teacher 1 was already aligning his practice with the new curriculum and responding to its demands before it became a requirement. This is the only reference any of these teachers made to $\mathrm{CfE}$ at the end of the Induction Year.

Teacher 1 was also aware of the difficulties of doing practical work caused by the particular equipment being used. Several teachers commented that the pupils noticed small variations in the brightness of lamps and that these variations meant that the pupils assumed that the different brightness of each lamp meant that a different current was flowing through each lamp. The importance Teacher 1 placed on practical work as a method to allow the children to collect good empirical data as a basis for their conceptual development was shown by his comments about pupils gathering qualitative data about parallel circuits containing lamps:

The parallel circuit is the one I found a lot of the time the pupils didn't think was wholly convincing.

[T1.3.3a]

He addressed this problem by setting up a carefully balanced parallel circuit for the pupils to consider so that they would have good data to think about during class discussions. This addressed the point raised by Abrahams (2011) about the difficulties pupils may have because of the "noise" they find in their experimental data.

Teacher 1 continued to consider the details of how to carry out practical work with pupils in his final interview:

I would like to do a lot more hands on practical work with them. We were doing basic Ohm's law, there might be resistors they burnt out, the little things like that. ... You are building up to: How do you use the voltmeter? How do you use the ammeter? Then bringing that together to show Ohm's law. For me Ohm's law is the key for it all really.

[T1.4.7]

As well as considering the practical details, such as teaching pupils to use ammeters and voltmeters, which is part of a physics teacher's GPK, he was also planning how to combine the parts of the pupils' knowledge to move towards the main aim, that the pupils would understand and be able to apply Ohm's law. This demonstrated Teacher 1's developing PCK about teaching this aspect of electricity.

\section{Case Study 2 -Use of Analogies}


Teacher 2 possessed an M. Eng. in Mechanical Engineering with Aeronautics and completed the PGDE Year qualified to teach Physics and Mathematics in schools. He had been placed in two state schools during the PGDE year and a third in the Induction Year. At the time of Interview 4 he was still working in the same school.

As the teachers grew in experience teaching different pupils in different schools, they realised that there were many different ways to teach electricity. The most effective teaching approach depended on the pupils not just on the teacher. This was summed up by Teacher 2:

I have been teaching for almost four years now [and] I think the thing that has changed about the way I teach electricity has probably been the number of different ways of doing it and I have found every kid's understanding of it is slightly different and what works for them is different.

[T2.4.6a]

As he gained more experience working with pupils and learned more about the pupils and the wider context, he also learned about the differences between pupils and learned from the pupils how to adapt his teaching to them, becoming a more effective teacher by using a number of different teaching approaches. As he said, "it will depend on the kids," [T2.3.3b].

This can be illustrated by considering Teacher 2's use of analogies over the course of the interviews. Table 6 shows how many analogies were used over the course of the interviews by all these teachers and divides them into three emergent categories: fluid analogies; anthropomorphic analogies; and other analogies. An example of a fluid analogy is to compare the flow of electrical current to the flow of current in a hosepipe. Anthropomorphic analogies included comparing electrical resistance to how easy or difficult pupils would find it to walk along a path (electrical wire) or to cross a muddy field (electrical resistor). The "other" analogies included any analogies which did not fit into the other two categories.

Table 6 Types of electrical analogy used by the teachers in the course of the four interviews.

\begin{tabular}{ccccc}
\hline Teacher & $\begin{array}{c}\text { Fluid } \\
\text { analogies }\end{array}$ & $\begin{array}{c}\text { Anthropomorphic } \\
\text { analogies }\end{array}$ & $\begin{array}{c}\text { Other } \\
\text { analogies }\end{array}$ & Totals \\
\hline 1 & 4 & 0 & 3 & 7 \\
2 & 9 & 14 & 1 & 24 \\
3 & 6 & 0 & 1 & 7 \\
4 & 1 & 3 & 1 & 5 \\
5 & 1 & 5 & 0 & 6 \\
6 & 0 & 5 & 0 & 5 \\
\hline Totals & 21 & 27 & 6 & 54 \\
\hline
\end{tabular}


Table 6 shows that Teacher 2 used more fluid and anthropomorphic analogies than the rest of the teachers. He mentioned analogies on 24 of the 54 occasions when these teachers used analogies. As well as using more analogies than the others. Teacher 2 also gave more considered pedagogical reasons for using analogies than the other teachers. As he gained more experience of particular learners and their context, Teacher 2 developed a more nuanced approach to using analogies in terms of which analogies would be used and with which classes. This shows the overlap between the development of his SMK for particular classes and his overall GPK.

In Interview 1, Teacher 2 used fluid analogies such as people standing on hosepipes to constrict the flow of water as an analogy for the effect of electrical resistance. By the time of Interview 3 at the end of the Induction Year, he tended to use anthropomorphic analogies with younger classes, such as people avoiding a "smelly road" [T2.3.3b] because he found that they worked well for "people people" [T2.3.8] who could visualise this type of analogy.

However, with older, examination classes he preferred that pupils knew the circuit rules (see Table 4) and were able to apply them:

... I tend to go straight with - this is how it works and go down the rules line for Standard Grade and the same for Higher. I do sometimes use water analogies for Higher because they're more able to visualise it. $\quad$ [T2.3.4a]

With Higher Physics classes and pupils aged $16+$ he did use fluid analogies. The strengths and limitations of this approach are discussed below.

During Interview 4, Teacher 2 discussed his use of analogies with different classes. In this case, rather than basing his comments on the age of the pupils, the comments were based on the course which the class were studying. (A pupil who was studying Intermediate 1 Physics would then need to study the Intermediate 2 Physics course before progressing to the Higher and the Advanced Higher Physics courses.)

I use more analogies - actually I don't tend to stick to a single one, they change level to level as well as we get up towards the Higher and Advanced Higher. Some of the things I might use with my Intermediate 1 class go out the window [because] they are not accurate enough. Some of the analogies start to fall apart when you start taking them any further.

[T2.4.8b]

Rather than discussing the limitations of analogies with classes Harrison \& Coll (2008), Teacher 2 decided to stop using electrical analogies with more advanced classes and to develop the pupils' understanding of electrical models instead.

There is limited evidence that Teacher 2 may have learned about some of these analogies from colleagues. At one point, when he was talking about a colleague who was trying to use the coal truck analogy with pupils in a rural area, he said:

He almost tried the coal truck analogy and then realised that none of the kids knew what a coal truck was!

[T2.3.8] 
Over the course of the four interviews, Teacher 2 developed his understanding of using analogies to teach electricity as he gained more experience of the learners and their context. He used mainly anthropomorphic analogies with younger pupils and carefully selected the ones which he would use with pupils in examination classes. In doing so, he demonstrated the way in which his SMK was adapted in different ways for different pupils, overlapping with his developing GPK and increasing CxK. Arguably, this demonstrated his developing PCK which drew on a variety of resources.

\section{Case Study 3 - Pragmatic Use of Mathematics}

Teacher 3 was a mature entrant to teaching with a B.Sc. in Electrical and Electronic Engineering; an M. Sc. and a Ph.D. who completed the PGDE Year qualified to teach Physics and Mathematics in schools. He had been placed in two state schools during the PGDE year and a third in the Induction Year. At the time of Interview 4, he had been employed as a supply teacher but had returned to work in industry. As a result, Teacher 3 only participated in Interviews 1, 2 and 3. Interview 1 was carried out before the first school placement. Interview 2 was carried out after Teacher 3 had one school placement teaching physics and one school placement teaching mathematics. As a result he had the same amount of experience teaching physics and mathematics as Teacher 2 during his second interview.

In Interview 1, before Teacher 3 had any experience in teaching in schools, his thinking was based around his own SMK. Unlike the other teachers at this stage, he did not suggest adapting his SMK for the pupils.

They've got two or three ways they can start at one bit and that'll lead them into the other parts. .... It's not a step by step thing

[T3.1.4b]

Although Teacher 3 did not discuss adapting his SMK for the pupils, he seemed to be aware that developing and applying SMK about electrical concepts would not be a straightforward process for the pupils.

At the time of Interview 2, he had spent six weeks teaching physics, but had not yet taught electricity. This experience had taught him that material should be presented to pupils in small steps:

$$
\text { It was just small steps they were taking. }
$$

However, by the time of Interview 3 after spending the Induction Year teaching physics in a school, he had developed a more task-orientated approach to teaching.

The logic and maths for solving the circuits are actually not as difficult as the basic concept - things either add up - you've always got constant voltages and currents flowing through things in series and parallel, so you can always break things down into series and parallel circuits and build everything up from there... 
At the end of the Induction Year, Teacher 3 had started to change his SMK into a form which was adapted to the pupils. He understood the physics of what was happening, but rather than explaining this to the pupils, he took a pragmatic mathematical approach that it was easier for pupils to learn the rules for voltage and current in series and parallel circuits (see Table 4) and to work things out from there rather than from first principles. This shows the link between his developing SMK and GPK.

Teacher 3 developed his GPK as he linked it to his SMK and began to change this into a form that was suitable for pupils:

You've just got to try and keep it as simple as possible - the only three things they've got to worry about are voltage, current and resistance-only a few simple laws and if they break the circuits down, it's all most of them will ever have to use.

[T3.3.6a]

Teacher 3 adopted this pragmatic approach because it was suitable for the majority of his pupils. At this task orientated stage in his development as a teacher, he was adapting his teaching to suit his pupils and therefore possibly showing the beginnings of a more pupilcentred approach.

Teacher 3's more pupil-centred approach was demonstrated by the way in which he dealt with questions about simple voltage divider circuits which required pupils to write down an explanation rather than carry out a calculation.

I was thinking I could have answered the question with more bullet points, I could have answered it with fewer bullet points - you've got to remember the way that is best for you - there isn't a particular way doing it. So what the pupils are basically doing is trying to memorise the answer and they are trying to remember the bullet points - that's why I never number them - I always use a bullet point, a marker, but I never number the steps to try and stop the pupils from memorising the answer.

[T3.3.5c]

This quotation shows a sophisticated approach to the problem. He has reflected on the fact that most pupils preferred to memorise explanations rather than to work out the solution from first principles. The Principal Teacher of Physics required that the answers to questions like this were written in the form of bullet points. Teacher 3's solution, which drew on his GPK and $\mathrm{CxK}$ as well as his SMK, was to use lists of points without numbers to encourage the pupils to understand what was happening in these circuits rather than trying to memorise a model example. Therefore, this is also an example of his developing PCK.

\section{Case Study 4 - This is what you need to know}

Teacher 4 had a B.Sc. in Mechanical Engineering and completed the PGDE Year qualified to teach Physics in schools. She had been placed in two state schools during the PGDE year and a third in the Induction Year. After the Induction Year she had obtained a permanent post in a rural school and at the time of Interview 4, had recently taken up a post in a second rural school. Teacher 4 did not take part in Interview 2 at the end of the PGDE Year. 
Teacher 4 was the only teacher who felt that she had not studied much electricity during her undergraduate degree and this was reflected in her comments about her developing SMK and its change into a form which was accessible to pupils:

At university, I didn't do a lot of electricity, or anything to do with electronics really.

[T4.3.6a]

However, in the same interview she reflected that:

I definitely feel more confident now, than I did before. I feel my knowledge of Physics in the Standard Grade courses has improved.

[T4.3.7a]

Despite the fact that Teacher 4 had not studied much electricity at university, during Interview 1 she answered all the questions about how she would teach it. When interviewed again two years later at the end of the Induction Year, she felt more confident about her SMK, and about how to adapt it for the pupils. Her increased curricular knowledge about the Standard Grade Physics course, studied by pupils between the ages of 14 and 15, contributed to her confidence.

Another reason for increasing confidence may have been her increased knowledge about the areas which pupils found difficult:

The whole of electricity was actually hard for them to understand. Voltage, current and resistance. A lot of kids get confused with each of them and the symbols. And they always remember voltage and volts because they're both a " $V$ ", but they couldn't really get current being an "I" and amps, again, because it's different.

[T4.3.4a]

This quotation illustrates Teacher 4's increased knowledge about the learners and their context and the overlap between her SMK and GPK.

Her commitment to learning more about learners and their context was also demonstrated at the time of Interview 4 when she had recently started working in a different rural school. She knew about the pupils' aspirations once they had left school:

A lot of pupils want to be electricians. A lot of them want to work as mechanics as well, so they need to know about things like electricity. [T4.4.6a]

Her solution to the pupils' difficulty in understanding electricity was to concentrate on what the pupils needed to know to meet their future needs and to do well in external examinations.

Just that they know the difference between current, resistance and voltage. And the main concept that I think they need to know if they are going to build on [it,] is what happens to voltage and current in series circuits and voltage and current in parallel circuits because they tend to get them mixed up. 
Like several of the other teachers, Teacher 4 thought that the pupils should know the circuit rules included in Table 4. Unlike the other teachers, she was very focused on the pupils knowing precisely what they needed to know to understand the topic. This demonstrated the increased confidence Teacher 4 discussed in Interview 3 about the overlap between her SMK and GPK. It also shows the interaction between her values as a teacher and her knowledge of learners and their context.

Another example of this overlap between Teacher 4's values and her knowledge of learners and their context was her Third Year Physics class with the unusual situation of pupils studying the same material but from the Intermediate 2 and Standard Grade Credit Level arrangements documents (SQA, 2004b, 2004e). The highest mark available in the Intermediate examinations is a Grade A and in Standard Grade, it is Level 1.

I am trying to gather evidence to see which is going to be the best for the pupils, and I've got about six in the class who would be better to sit Intermediate 2 because they are more likely to get an A than a 1.

[T4.4.3b]

However, at that time, if the pupils applied to study at university, a Grade A in an Intermediate 2 examination scored more points than a Standard Grade examination at Level 1 and was therefore potentially more useful.

Overall, as Teacher 4's confidence in her own SMK developed and she gained greater knowledge about the pupils and their context and needs, she demonstrated her values in her commitment to helping the pupils to develop their own knowledge

\section{Case Study 5 - Predict - Observe - Explain (POE)}

Teacher 5 came to teaching as a mature entrant with a B.Sc. in Electronics and Electrical Engineering and completed the PGDE Year qualified to teach Physics in schools. He was placed in a private school and a state school during his PGDE year, and a state school during the Induction Year. He had moved from working in mainstream schools at the time of Interview 3 to the very different context of a Residential School, where he was working with pupils who had severe Additional Support Needs (ASN, ("Education (Additional Support for Learning) (Scotland) Act," 2004)). As a result, Teacher 5 had adapted his teaching approach to the needs of the pupils that he was working with. These pupils were very different from pupils in mainstream schools and he worked with them in a different way:

You can't take anything for granted. What you find is that you have to consistently reinforce things and go back over things.

[T5.4.8a]

This is an example of Teacher 5 combining his knowledge of the new context and the learners within it with his general pedagogical knowledge. As a result, his PCK about working with pupils in a Residential School had been transformed. In addition, this quotation also shows Teacher 5's pupil-centred approach to teaching and learning. He has adapted his approach to the pupils rather than expecting the pupils to adapt to the teacher's approach. 
The way in which Teacher 5 learned from the pupils can also be illustrated by considering changes in his use of questioning with different pupils. The interview schedule asked the teachers to explain how they taught electrical concepts. As a result, most of the teachers did not give examples of the types of questioning they used in classrooms, despite the fact that questioning played an important part in these teachers' classroom practice. The exception was Teacher 5, who frequently structured his answers in terms of the questions he would ask pupils to advance their thinking.

I would tend to do it a different way. I think the last time we talked I tended to just explain it. What can you say will happen to the two bulbs - will they be brighter? Will they be dimmer? Will they be the same? Get them to speculate on it. Probably I would adopt a more questioning approach. [T5.2.1a]

Before Teacher 5 went on his first school placement, he discussed explaining to pupils what they needed to know. However, by the end of the PGDE year when he had gained some experience teaching, he demonstrated some of the ways in which he had used questioning. One way he used questions with pupils was to embed them in a Predict - Observe - Explain (POE) routine, White and Gunstone (1992), to encourage pupil dialogue about practical work. Teacher 5 did not mention a POE approach in his first interview and initially developed a variant of a POE routine with pupils in his second placement school and was able to adapt it for use in his Induction School, as he learned what worked with different pupils in a different context. The five steps in the routine were identified to be an initial visual stimulus or demonstration to focus attention; initial pupil observation or reminder of prior knowledge; pupils predict what will happen; pupils observe or carry out an experiment and finally discuss and explain what was observed. All of these aspects can be seen in the quotation above. While there is no explicit mention of SMK in the quotation above, it can be deduced that Teacher 5 is confident in his SMK about this topic and translating his own knowledge into a format that the pupils can understand. As he reflected on his teaching, Teacher 5 has developed his GPK, shown by his development away from a teacher-centred approach to an active and pupil-centred approach to learning.

Nevertheless, despite discussing some of the interactive ways in which he used questioning with pupils in mainstream schools, he reflected on the different approach he was adopting in the Residential School:

How I explain this to a child now would differ from how I would have done it at the end of our Induction after the year in a mainstream school. [T5.4.8a]

As well as explaining concepts in a different way, Teacher 5 also adopted a different approach to talking about his approach to teaching basic simple series circuits and questioning in the Residential School:

With some of the brighter pupils, I explain [a series circuit] in terms of energy. This [battery] is providing more energy. So, what do you think? If there is more energy coming out here, what do you think is going happen to the bulb? Well, okay, it's going get brighter, but...

[T5.4.1a] 
This quotation shows that Teacher 5 was using a different approach with the "brighter pupils" than the other pupils in the class. Although he asks the brighter pupils in the Residential School questions, there seemed to be less scope for speculation than in quotation T5.2.1a (above) where he discussed the POE approach that he had developed in mainstream schools.

\section{Case Study 6 - Know the Rulles}

Teacher 6 came to teaching as a mature entrant with a B. Sc. in Mechanical Engineering and completed the PGDE Year qualified to teach Physics and Mathematics in schools. He took part in Interviews 1, 2 and 3. He was contacted to take part in Interview 4, but was teaching mathematics rather than physics at the time and therefore did not take part in the final round of interviews. As a result, this case study considers the survival and task-orientated phases of teacher development.

Teacher 6 had disliked the electricity topic when he was a pupil. During Interview 1 he reported that, "electricity's probably going to be my second least favourite subject" [T6.1.6c]. When prompted by the interviewer about his least favourite subject, he replied "It's going to be electronics" [T6.1.6c]. However, during Interview 2 at the end of the PGDE year Teacher 6 saw teaching electricity and electronics as a topic which would enable him to develop as a teacher.

\section{I think it will be good to teach a subject which I didn't enjoy myself, to try and make it more enjoyable over the next couple of years. \\ [T6.2.6c]}

His commitment to making the subject more enjoyable, presumably for the pupils, was an expression of his values as a teacher and would also involve developing several other components of PCK, including reflection. The other aspects of PCK potentially involved would be transforming his SMK about teaching electricity; finding out more about the pupils and their wider context to be able to develop ways to engage them.

Teacher 6 focused on clarity of the pupils' thinking in his interviews. The two aspects of this clarity of thinking included in the case study are about pupils knowing the rules for series and parallel circuits and how these can be used to understand voltage divider circuits.

Teacher 6 discussed all of the rules included in Table 4 in Interviews 1,2 and 3. When he reflected on this in Interview 3, he felt that the pupils needed to know what the circuit was and the rules which they could use to carry out calculations:

I would maybe just say what I said at the beginning - it's all about getting a clear circuit, or a clear set of rules and always apply that to all your teachingalways going back to them, rule 1, rule 2, rule 3, rule 4 .

[T6.3.6a]

For all of these teachers, pupils were expected to learn and apply the relevant circuit rules. At the end of the Induction Year, Teacher 6 took a mainly task-orientated approach to his teaching, which may have been becoming pupil centred. This more pupil-centred approach could be seen when he talked about teaching the pupils how to set out the steps of numerical questions:

I took out this jotter* for the Standard Grade and Intermediate 2 pupils, and I said look at this pupil - This is a Higher jotter. Look at the equation they use 
- 1 over R1 plus 1 over R2 - they didn't put one over RT equals - I could really lose my rag [temper] with this - that means nothing, nothing at all. Then I would say to them - do you want to know who this is? Turn over this jotter and see who it belongs to and see if anyone knows them? And it was my old jotter!

[T6.3.4c]

*In Scottish English, a "jotter" is an exercise book.

By using the example of a pupil writing the equation for adding two resistors in parallel $1 / R_{\text {Total }}=1 / R_{1}+1 / R_{2}$ as the non-equation $1 / R_{1}+1 / R_{2}$, Teacher 6 was able to make a point about writing equations to his pupils in a memorable way because he had been the pupil who had made the mistake. By reflecting on the way in which he had made the point in the interview, he demonstrated his increasing GPK.

Examining Teacher 6's changing approach to teaching about voltage divider circuits may suggest that he was beginning to move from a task-orientated approach in Interview 2 to a more impact-orientated approach in Interview 3. A more pupil-centred approach to deal with pupils' conceptual difficulties was demonstrated in Interview 2. Pupils were provided with a step-by-step model answer which they could adapt as they grew in understanding:

I think the point where they all struggled most was the voltage divider circuit. I reflected on what I was doing and then started to build up the ideal answer.

[T6.2.8]

However, as Teacher 3 had also discovered, different teachers used a different number of steps, so at the time of his third and final interview, Teacher 6 used a different approach to teaching about voltage dividers by using a practical demonstration. The demonstration started with two equal resistors in series and discussed what the pupils expected to happen before changing the value of one of the resistors:

I would try to start off with equal resistors, so that they get the same voltage [across each resistor. Then,] let's just change the resistance of one of them so they start to see that if this resistance goes up, the voltage across it goes up

[T6.3.5a]

As a result, the pupils gained an understanding of what was happening physically before they started carrying out calculations or writing explanations. This appeared to be a change since Teacher 6's previous interview during his PGDE year, when he concentrated on a procedural approach to answering questions about voltage dividers rather than building the pupils' physical experience with the circuits.

\section{Discussion}

\section{General findlings}

During the first interview at the beginning of the PGDE course, all the student teachers, except Teacher 3, expressed a degree of concern about transforming their own SMK about teaching electricity into a format which pupils could understand. This is consistent with the 
survival-orientated stage of early teacher development (Fuller and Brown, 1975 and Katz, 1972 and 2011). However, at the time of the second interview towards the end of the PGDE year, the student teachers no longer expressed the need to transform their SMK in this way and seem to have become more focused on the task of teaching the pupils about electricity and to have moved on to the task (Fuller \& Brown) or consolidation stage (Katz) before the beginning of the Induction Year.

Several studies have shown that secondary physics teachers often share the same misconceptions as their pupils (Engelhardt \& Beichner, 2004; Mualem \& Eylon, 2010; Planinic, 2006). However, there was no evidence in the interviews with the beginning teachers that they did share the pupils' misconceptions about electricity. This is probably due to the rigorous demands of subject-specific entry to the Scottish PGDE (Scottish Government, 2009). Additionally, most of the beginning teachers had completed a class about how to teach basic electrical concepts at the beginning of the PGDE year and before they were interviewed which had probably influenced their responses.

One of the common features of these teachers' developing GPK was their generally pragmatic approach to using practical work with their classes. All of the teachers accepted practical work as an unproblematic feature of their practice as teachers. None of them discussed any criticism of the nature and purpose of practical work along the lines highlighted by Hodson (1990, 1993), Abrahams \& Saglam (2010) or Abrahams (2011). Teacher 1 gave the strongest rationale for the use of practical work as an integral part of his practice and a method to allow pupils to engage in their learning and therefore to understand their observations and the related theory.

The teachers all discussed different teaching approaches such as using questioning; practical work; solving numerical problems; writing explanations and problem solving which had been introduced to them during their PGDE year. However, given their different contexts, they discussed using these approaches in different proportions and ways. Some of the common problems they discussed were that it was often difficult to find matched lamps to show younger pupils that the current around a series circuit is the same. A version of this problem with older pupils was that they found it difficult to interpret the readings on digital meters. To the teachers a reading of 1.49 amperes was the same as a reading of 1.50 amperes. However, to the pupils, these readings were different.

Another problem which some of the teachers encountered was that most pupils found it difficult to use the equation $1 / R_{\text {Total }}=1 / R_{1}+1 / R_{2}$ to add two resistors in parallel. This happened because most of them found it difficult to carry out calculations involving fractions without using a calculator. However, in addition, the pupils were not sufficiently familiar with finding reciprocals, either manually or by using a calculator, to complete the final step in the calculations to reach the final answer. The teachers adapted to the pupils' mathematical needs to enable them to answer this type of question successfully.

Some of the points about the teachers' developing GPK in the previous paragraphs overlapped with the teachers developing contextual knowledge, although their contexts and therefore developing $\mathrm{CxK}$ were different. However, the most striking common features of their CxK was the way in which they referred to "their" pupils and the way in which they reflected on what had happened in their classes by relating stories (vignettes) about particular pupils to illustrate their points.

In terms of the general findings, the teachers' separate knowledge bases were developing and, in addition, the complex overlap between the separate knowledge bases also showed that the 
teachers were developing their PCK at the same time. This point also holds for the case study findings discussed below.

\section{Case study findings}

Table 7 summarises the teaching approaches which have been included in the case studies. The first column in Table 7 also considers whether the beginning teachers are pupil or teacher centred in their approach to teaching in their final interview. The four teachers who were interviewed two-and-a-half years after the end of the Induction Year were wholly pupil centred in their approaches to teaching. Only Teachers 3 and 6 were teacher centred at the time of their final interviews, but were beginning to show some signs of a more pupil-centred approach. However, Teachers 3 and 6 were the only ones who were interviewed for the last time at the end of the Induction Year and as a result had less teaching experience than the other teachers.

Table 7 Teaching approaches included in the case studies of the six teachers.

\begin{tabular}{|c|c|c|c|c|c|c|c|}
\hline Teacher & $\begin{array}{c}\text { Teacher- } \\
\text { pupil- } \\
\text { centred } \\
\text { approach } \\
\text { (Values) }\end{array}$ & $\begin{array}{c}\text { Predict- } \\
\text { Observe- } \\
\text { Explain } \\
\text { (GPK) }\end{array}$ & $\begin{array}{l}\text { Know the } \\
\text { rules } \\
\text { (SMK / } \\
\text { GPK) }\end{array}$ & $\begin{array}{c}\text { Using } \\
\text { practical } \\
\text { work to } \\
\text { develop } \\
\text { understand- } \\
\text { ing } \\
\text { (GPK) }\end{array}$ & $\begin{array}{l}\text { This is what } \\
\text { you need to } \\
\text { know } \\
\text { (SMK / } \\
\text { GPK) }\end{array}$ & $\begin{array}{c}\text { Use of } \\
\text { analogies } \\
\text { (SMK / } \\
\text { GPK) }\end{array}$ & $\begin{array}{c}\text { Pragmatic } \\
\text { use of } \\
\text { mathematics } \\
\text { (SMK / } \\
\text { GPK) }\end{array}$ \\
\hline 1 & $\begin{array}{c}\text { Pupil } \\
\text { centred }\end{array}$ & & & Yes & & & \\
\hline $2 *$ & $\begin{array}{l}\text { Pupil } \\
\text { centred }\end{array}$ & & Yes & & & Yes & \\
\hline $3 * *$ & $\begin{array}{l}\text { Teacher } \\
\text { centred }\end{array}$ & & Yes & & & & Yes \\
\hline 4 & $\begin{array}{l}\text { Teacher } \\
\text { centred }\end{array}$ & & Yes & & Yes & & \\
\hline 5 & $\begin{array}{l}\text { Pupil } \\
\text { centred }\end{array}$ & Yes & & & & & \\
\hline $6^{* *}$ & $\begin{array}{l}\text { Teacher } \\
\text { centred }\end{array}$ & & Yes & Yes & & & \\
\hline
\end{tabular}

*Teacher 2 did not participate in Interview 2.

**Teachers 3 and 6 did not participate in Interview 4.

Another similarity between the teachers was that all of them had moved from Fuller \& Brown's survival-orientated stage to the task-orientated stage. According to their model, this would be expected for teachers with several years of experience. It is possible that Teachers 2, 4 and 5 were moving towards a more outcome-orientated stage because they talked about the outcomes they felt were desirable for their pupils.

At the beginning of the PGDE course, most of these teachers, except Teachers 3 and 4, felt that the issue with their SMK was about changing it into a form which was suitable for use with pupils. Teacher 4 felt that she had not studied enough electricity at university to feel 
confident teaching it. However, as she gained experience teaching the topic and learning about the curricular content, she became more confident about teaching it.

The biggest change in SMK was observed where it overlapped with GPK. All of the teachers stated that some approaches worked better with some pupils than with others. They learned from the pupils in their individual contexts how to adapt their SMK and teaching approaches to them. (An example of this is discussed in the general findings section in relation to pupils' mathematical knowledge about fractions.) More specifically, Teacher 2 adapted his use of analogies to the age and intellectual stage of his pupils. It is unclear why he chose to use more analogies than the rest of the teachers (see Table 6), but it is possible that he learned about this approach from colleagues.

Another example of the overlap between SMK and GMK is the way in which Teachers 2, 3, 4 and 6 discussed the need for pupils to "know the rules" for current and voltage in simple circuits. They had selected from their own SMK the relationships which the pupils needed to know and then developed a GPK approach which allowed them to apply these ideas. Teacher 3 took this further when he decided that pupils could simply pragmatically apply these rules and reach numerical answers using the rules without necessarily understanding the underlying physics.

Teacher 6's approach had similarities to Teacher 4's pragmatic approach to teaching pupils what they needed to know to solve problems or answer questions. Both seemed to be more concerned that pupils could answer questions rather than necessarily understanding the concepts behind the rules which they were applying. Both teachers felt that taking this approach was appropriate in their schools.

As their GPK expanded, all of these teachers developed a number of classroom management routines and pedagogical routines. For example, Teacher 1 had trained pupils in his routines for collecting and returning apparatus. This fitted with the value he placed on using practical work to develop pupils' understanding. Teacher 6 also placed a high value on pupils carrying out practical work. Teacher 5 used a Predict - Observe - Explain schema to introduce practical work. As well as demonstrating his commitment to the value of practical work, a POE approach also demonstrated the value he placed on questioning as a way to involve his pupils in their own learning. In the context of written work, Teachers 3 and 6 discussed the instructions which they gave to pupils about how to set out the written steps to find the answer to a numerical question. This explicitly systematic approach may have allowed them to internalise routines which they could then use independently.

All of these teachers discussed learning about a new context and new pupils when they moved to a different school. The most immediate factor affecting the teachers in these interviews was their interaction with pupils. During the first interview, the teachers had no systematic experience in schools. By the time of the second interview, they all had experience of two schools and talked about similarities and differences between the pupils in the two schools. The comparison of the context and pupils in different schools continued at the end of the Induction Year (third interview) and again two-and-a-half years later (fourth interview).

The case studies demonstrate the developing nature of these teachers' PCK. The developmental aspect relates more closely to Magnusson et al.'s (1999) concept of pedagogical content knowing than Shulman's $(1986,1987)$ pedagogical content knowledge. Nevertheless, because the focus of this study was on the development of the beginning teachers' SMK and GPK about teaching electricity, the tripartite division of Shulman's PCK 
provided a useful theoretical framework for the analysis. These teachers all had or developed (Teacher 4) the necessary SMK to teach electricity. However, while this was necessary, it was not sufficient as all these teachers linked the development of their approaches to teaching electricity to their separately developing GPK and CxK as they learned from their pupils and adapted their teaching to them. Although the concept of PCK was not introduced to these teachers during their PGDE year, they appeared to be drawing on and developing their separate knowledge bases while also transforming them into the new form of knowledge specific to teachers: PCK. Thus, these teachers, like many researchers, lie between the extremes of Gess-Newsome's (1999) integrative - transformative continuum.

\section{Implications}

This article has reported the results of a study in which six beginning teachers reflected about how they taught electricity over a period of four-and-a-half years. Combining repeated interviews with direct observation and stimulated video recall (see Hubber, Tytler, \& Haslam, 2010; Lyle, 2003), would develop a fuller understanding of what happens to beginning teachers as they develop their PCK about teaching electricity. For example, the teachers here did not report using a large number of metaphors or analogies when they taught electricity. There is a lack of agreement about the best way to teach electricity, see Mulhall, McKittrick, \& Gunstone (2001) and Gunstone, Mulhall, \& McKittrick (2009). There is scope to explore the metaphors, analogies and models which teachers use in the classroom. These could suggest areas where teachers and researchers could usefully collaborate.

One of the implications of this for initial teacher education is that student teachers would benefit if they were explicitly taught about PCK and exploring ways to develop its components. Parker $(2004,2006)$ examined some of these issues for the primary sector. Kind (2009a) investigated the development of her secondary science student teachers' SMK when teaching within their area of subject expertise and outside it. A different approach using Content Representations (CoRes) has been developed by Loughran et al. (2008) and explored by Hume \& Berry (2011). This allows (student) teachers to explicitly link their SMK to their developing GPK as their PCK develops. Using CoRes as a way to develop and explore student teachers' PCK about electricity could be a useful next step for ITE tutors and students.

One of the findings of this study is that the important role of teachers learning from pupils has been somewhat under-emphasised in the literature about teacher development. Both the Fuller \& Brown $(1975)$ and Katz $(1972,2011)$ models suggest that teachers begin to routinise their classroom actions and can become "stuck" at a particular stage of development. When does the beginning teacher develop such routinised teaching that it is unhelpful and actually blocks further development? Would a focus on teachers learning from pupils help to prevent this type of unhelpful, routinised teaching?

[Word count $=14$ 514]

\section{References}

Abell, S., Rogers, M., Hanuscin, D., Lee, M., \& Gagnon, M. (2009). Preparing the Next Generation of Science Teacher Educators: A Model for Developing PCK for Teaching Science Teachers. Journal of Science Teacher Education, 20(1), 77-93. 
Abrahams, I. (2011). Practical Work in Secondary Science: A Minds-on Approach London: Continuum.

Abrahams, I., \& Saglam, M. (2010). A Study of Teachers' Views on Practical Work in Secondary Schools in England and Wales. International Journal of Science Education, 32(6), $753-768$.

Arons, A. B. (1997). Teaching Introductory Physics. New York: John Wiley and Sons Inc.

Avraamidou, L., \& Zembal-Saul, C. (2010). In search of well-started beginning science teachers: Insights from two first-year elementary teachers. Journal of Research in Science Teaching, 47(6), 661-686.

Berry, A., Loughran, J., Smith, K., \& Lindsay, S. (2009). Capturing and Enhancing Science Teachers' Professional Knowledge. Research in Science Education, 39(4), 575-594.

Bishop, K., \& Denley, P. (2007). Learning Science Teaching: Developing a Professional Knowledge Base. Maidenhead: Open University Press.

Borges, A. T., \& Gilbert, J. K. (1999). Mental models of electricity. International Journal of Science Education, 21(1), 95 - 117.

Boyatzis. (1998). Transforming qualitative information: thematic analysis and code development. Thousand Oaks, CA Sage Publications.

Bryce, T. G. K. (2008). Assessment in Scottish Schools. In T. G. K. Bryce \& W. M. Humes (Eds.), Scottish Education: Beyond Devolution (3rd ed., pp. 581-594). Edinburgh: Edinburgh University Press.

Bryce, T. G. K., \& Humes, W. M. (Eds.). (2008). Scottish Education: Beyond Devolution (3rd ed.). Edinburgh: Edinburgh University Press.

Cochran, K. F., DeRuiter, J. A., \& King, R. A. (1993). Pedagogical Content Knowing: An Integrative Model for Teacher Preparation. Journal of Teacher Education, 44(4), 263-272.

Cohen, R., Eylon, B., \& Ganiel, U. (1983). Potential difference and current in simple electric circuits: A study of students' concepts. American Journal of Physics, 51(5), 407-412.

Cooke, M., \& Bejtka, K. (2010). Programme for International Student Assessment (PISA) 2009 Highlights from Scotland's Results. Edinburgh: Scottish Government Retrieved from http://www.scotland.gov.uk/Resource/Doc/334567/0109376.pdf.

Curriculum Review Group. (2004). A Curriculum for Excellence: The Curriculum Review Group Report. Edinburgh: Scottish Executive.

Driver, R., Guesne, E., \& Tiberghien, A. (1985). Children's Ideas in Science. Buckingham: Buckingham: Open University Press.

Duit, R., Jung, W., \& von Rhoeneck, C. (1985). Aspects of understanding electricity. Proceedings of an international workshop in Ludwigsburg 1984. Kiel: Schmidt \& Klaunig.

Duit, R., \& von Rhöneck, C. (1998). Learning and Understanding Key Concepts of Electricity. In A. Tiberghien, E. L. Jossem \& J. Barojas (Eds.), Connecting Research in 
Physics Education with Teacher Education Ohio: International Commission on Physics Education

Education (Additional Support for Learning) (Scotland) Act, Scottish Parliament (2004).

Edwards, D. (2006). Transcription. In V. Jupp (Ed.), The Sage Dictionary of Social Research Methods. London: Sage Publications.

Engelhardt, P. V., \& Beichner, R. J. (2004). Students' understanding of direct current resistive electric currents. American Journal of Physics, 72(1), $98-115$.

Fuller, F., \& Brown, O. (1975). Becoming a teacher. In K. Ryan (Ed.), Teacher Education (Vol. 74th Yearbook of the National Society for the Study of Education. Part 2, pp. 25-52). Chicago: University of Chicago Press.

Geertz, C. (1973). The Interpretation of Cultures: Selected Essays. London: Hutchinson.

General Teaching Council for Scotland. (2006a). The Standard for Full Registration. Edinburgh: GTCS.

General Teaching Council for Scotland. (2006b). Standard for Initial Teacher Education. Edinburgh: GTCS.

Gess-Newsome, J. (1999). Pedagogical Content Knowledge: An Introduction and Orientation. In J. Gess-Newsome \& N. G. Lederman (Eds.), Examining Pedagogical Content Knowledge (pp. 3-17). Dordrecht: Kluwer Academic Publishers.

Gess-Newsome, J., Cardenas, S., Austin, B. A., Carlson, J., Gardner, A. L., Stuhlsatz, M. A. M., ... Wilson, C. D. (2011). Impact of Educative Materials and Transformative Professional Development on Teachers PCK, Practice, and Student Achievement. Paper presented at the NARST, Dallas, USA.

Gess-Newsome, J., \& Lederman, N. (Eds.). (1999). Examining Pedagogical Content Knowledge. Dordrecht: Kluwer Academic Publishers.

Grossman, P. L. (1990). The making of a teacher : teacher knowledge and teacher education. New York: Teachers College Press.

Gunstone, R., Mulhall, P., \& McKittrick, B. (2009). Physics Teachers' Perceptions of the Difficulty of Teaching Electricity. Research in Science Education, 39(4), 515-538.

Halloun, I. A., \& Hestenes, D. (1985). Common sense concepts about motion. American Journal of Physics, 53(11), 105601965.

Harrison, A. G. (2008). Multiple Analogies Are Better Than One-Size-Fits-All Analogies. In A. G. Harrison \& R. K. Coll (Eds.), Using ANALOGIES in Middle and Secondary SCIENCE Classrooms: - the FAR Guide - An Interesting Way to Teach With Analogies. Thousand Oaks, California: Corwin Press.

Harrison, A. G., \& Coll, R. K. (Eds.). (2008). Using ANALOGIES in Middle and Secondary SCIENCE Classrooms: - the FAR Guide - An Interesting Way to Teach With Analogies. Thousand Oaks, California: Corwin Press. 
Hart, C. (2008). Models in Physics, Models for Physics Learning, and Why the Distinction may Matter in the Case of Electric Circuits. Research in Science Education, 38(5), 529-544.

Heller, P. M., \& Finley, F. N. (1992). Variable uses of alternative conceptions: A case study in current electricity. Journal of Research in Science Teaching, 29(3), 259-275.

Henze, I., van Driel, J. H., \& Verloop, N. (2007a). The Change of Science Teachers' Personal Knowledge about Teaching Models and Modelling in the Context of Science Education Reform. International Journal of Science Education, 29(15), 1819-1846. doi: $10.1080 / 09500690601052628$

Henze, I., van Driel, J. H., \& Verloop, N. (2007b). Science teachers' knowledge about teaching models and modelling in the context of a New Syllabus on public understanding of science. Research in Science Education, 37(2), 99-122.

Henze, I., van Driel, J. H., \& Verloop, N. (2008). Development of Experienced Science Teachers' Pedagogical Content Knowledge of Models of the Solar System and the Universe. International Journal of Science Education, 30(10), 1321-1342. doi: $10.1080 / 09500690802187017$

HMIE. (2005). HMIE Report to SEED on the Delivery of The National Priorities. Edinburgh: HMIE Retrieved from http://www.hmie.gov.uk/documents/publication/hmiednp.pdf.

Hodson, D. (1990). A critical look at practical work in school science. School Science Review, 70(256), 33-40.

Hodson, D. (1993). Re-thinking Old Ways: Towards A More Critical Approach To Practical Work In School Science. Studies in Science Education, 22(1), 85 - 142.

Horne, J., Bejtka, K., \& Miller, S. (2008). Trends in International Maths and Science Survey (TIMSS) 2007 - Highlights From Scotland's Results. Edinburgh: Scottish Government Retrieved from http://www.scotland.gov.uk/Resource/Doc/288097/0088001.pdf.

Hubber, P., Tytler, R., \& Haslam, F. (2010). Teaching and Learning about Force with a Representational Focus: Pedagogy and Teacher Change. Research in Science Education, 40(1), 5-28. doi: 10.1007/s11165-009-9154-9

Hume, A., \& Berry, A. (2011). Constructing CoRes - a Strategy for Building PCK in Preservice Science Teacher Education. Research in Science Education, 41(3), 341-355. doi: $10.1007 / \mathrm{s} 11165-010-9168-3$

Katz, L. G. (1972). Developmental Stages of Preschool Teachers. Elementary School Journal, 73(1), 50-54.

Katz, L. G. (2011). The Developmental Stages of Teachers Retrieved 13th October 2011, from http://ceep.crc.uiuc.edu/pubs/katz-dev-stages.html\#f1

Kind, V. (2009a). A Conflict in Your Head: An exploration of trainee science teachers' subject matter knowledge development and its impact on teacher self-confidence. International Journal of Science Education, 31(11), 1529-1562.

Kind, V. (2009b). Pedagogical content knowledge in science education: perspectives and potential for progress Studies in Science Education, 45(2), 169 - 204. 
Kücüközer, H., \& Demirci, N. (2008). Pre-service and in-service physics teachers' ideas about simple electric circuits. Eurasia Journal of Mathematics, Science and Technology Education, 4(3), 303-311.

Learning and Teaching Scotland. (2002). Assessment development programme action plan. Glasgow: Learning and Teaching Scotland.

Learning and Teaching Scotland. (2008). Curriculum for Excellence Retrieved 7 August 2008, from http://www.Itscotland.org.uk/curriculumforexcellence/index.asp

Learning and Teaching Scotland. (2010). Sciences: Experiences and outcomes Retrieved 10.11.11, from

http://www.Itscotland.org.uk/learningteachingandassessment/curriculumareas/sciences/ eandos/index.asp

Lee, E., Brown, M. N., Luft, J. A., \& Roehrig, G. H. (2007). Assessing Beginning Secondary Science Teachers' PCK: Pilot Year Results. School Science and Mathematics, 107(2), 52-60. doi: 10.1111/j.1949-8594.2007.tb17768.x

Loughran, J., Mulhall, P., \& Berry, A. (2006). Understanding and Developing Science Teachers' Pedagogical Content Knowledge. Rotterdam: Sense Publishers.

Loughran, J., Mulhall, P., \& Berry, A. (2008). Exploring Pedagogical Content Knowledge in Science Teacher Education. International Journal of Science Education, 30(10), 1301-1320. doi: 10.1080/09500690802187009

Lyle, J. (2003). Stimulated recall: a report on its use in naturalistic research. British Educational Research Journal, 29(6), 861-878. doi: 10.1080/0141192032000137349

Magnusson, S., Krajcik, J., \& Borko, H. (1999). Nature, sources and development of pedagogical content knowledge for science teaching. In J. Gess-Newsome, Lederman, N.

(Ed.), Examining Pedagogical Content Knowledge (pp. 95-132). Dordrecht, The Netherlands: Kluwer Academic Press.

McDermott, L. C., Heron, P. R. L., Shaffer, P. S., \& Stetzer, M. R. (2006). Improving the preparation of K-12 teachers through physics education research. [Article]. American Journal of Physics, 74(9), 763-767.

McNally, J., \& Blake, A. (Eds.). (2010). Improving Learning in a Professional Context: a research perspective on the new teacher in school. London: Routledge.

Merriam, S. B. (1998). Case study research in education: A qualitative approach. San Francisco: Jossey-Bass.

Merriam, S. B., \& Associates. (2002). Qualitative research in practice : examples for discussion and analysis. San Francisco: Jossey-Bass.

Millar, R. (2005). Teaching about energy Retrieved April 2011, from http://www.york.ac.uk/media/educationalstudies/documents/research/Paper11Teaching aboutenergy.pdf

Millar, R. (2008). Forces and motion Retrieved 1.6.2008, from

http://nationalstrategies.standards.desf.gov.uk/node/64899 
Mualem, R., \& Eylon, B. S. (2010). Junior high school physics: Using a qualitative strategy for successful problem solving. Journal of Research in Science Teaching, 47(9), 1094-1115. doi: $10.1002 /$ tea.20369

Mulhall, P., McKittrick, B., \& Gunstone, R. (2001). A Perspective on the Resolution of Confusions in the Teaching of Electricity. Research in Science Education, 31(4), 575-587.

Nilsson, P. (2008). Teaching for Understanding: The complex nature of pedagogical content knowledge in pre-service education. International Journal of Science Education, 30(10), $1281-1299$.

Nilsson, P., \& van Driel, J. H. (2010). Teaching together and learning together - Primary science student teachers' and their mentors' joint teaching and learning in the primary classroom. Teaching and Teacher Education, 26(6), 1309-1318. doi: 10.1016/j.tate.2010.03.009

Nilsson, P., \& van Driel, J. H. (2011). How Will We Understand What We Teach? - Primary Student Teachers' Perceptions of their Development of Knowledge and Attitudes Towards Physics. Research in Science Education, 41(4), 541-560. doi: 10.1007/s11165-010-9179-0

Pardhan, H., \& Bano, Y. (2001). Science teachers' alternate conceptions about directcurrents. International Journal of Science Education, 23(3), 301 - 318.

Parker, J. (2004). The synthesis of subject and pedagogy for effective learning and teaching in primary science education. British Educational Research Journal, 30(6), 819-839. doi: $10.1080 / 0141192042000279521$

Parker, J. (2006). Exploring the Impact of Varying Degrees of Cognitive Conflict in the Generation of both Subject and Pedagogical Knowledge as Primary Trainee Teachers Learn about Shadow Formation. International Journal of Science Education, 28(13), 1545 - 1577.

Picciarelli, V., Di Gennaro, M., Stella, R., \& Conte, E. (1991a). A Study of University Students' Understanding of Simple Electric Circuits Part 1: Current in d.c. Circuits. European Journal of Engineering Education, 16(1), 41-56. doi: 10.1080/03043799108939503

Picciarelli, V., Di Gennaro, M., Stella, R., \& Conte, E. (1991b). A Study of University Students' Understanding of Simple Electric Circuits Part 2: Batteries, Ohm's Law, Power Dissipated, Resistors in Parallel. European Journal of Engineering Education, 16(1), 57-71. doi: $10.1080 / 03043799108939504$

Planinic, M. (2006). Assessment of difficulties of some conceptual areas from electricity and magnetism using the Conceptual Survey of Electricity and Magnetism. [Article]. American Journal of Physics, 74(12), 1143-1148.

Scottish Executive. (2000). Envirommental Studies: Society, Science and Technology 5-14 National Guidelines. Edinburgh: Learning and Teaching Scotland.

Scottish Government. (2005). AifL - Assessment is for Learning information sheet. Retrieved from http://www.scotland.gov.uk/Resource/Doc/69582/0017827.pdf.

Scottish Government. (2009). Memorandum on Entry Requirements to Courses of Initial Teacher Education in Scotland. Edinburgh: Scottish Government, Retrieved from http://www.scotland.gov.uk/Resource/Doc/305242/0095757.pdf. 
Scottish Government. (2010). SQA Examination Results in Scottish Schools: 2009/2010.

Edinburgh: Scottish Government Retrieved from

http://www.scotland.gov.uk/Resource/Doc/325934/0105032.pdf.

Sharma, S. V., \& Sharma, K. C. (2007). Concepts of force and frictional force: the influence of preconceptions on learning across different levels. Physics Education, 42(5), 516-521.

Shulman, L. S. (1986). Those Who Understand: Knowledge Growth in Teaching.

Educational Researcher, 15(2), 4-14.

Shulman, L. S. (1987). Knowledge and Teaching: Foundations of the New Reform. Harvard Educational Review, 57(1), 1-22.

Singh, C., \& Rosengrant, D. (2003). Multiple-choice test of energy and momentum concepts. American Journal of Physics, 71(6), 607 - 617.

Sperandeo-Mineo, R. M., Fazio, C., \& Tarantino, G. (2006). Pedagogical content knowledge development and pre-service physics teacher education: A case study. Research in Science Education, 36(3), 235-268. doi: 10.1007/s11165-005-9004-3

SQA. (2004a). Higher Physics (6th ed.). Glasgow: Scottish Qualifications Authority.

SQA. (2004b). Intermediate 2 Physics (5th ed.). Glasgow: Scottish Qualifications Authority.

SQA. (2004c). Physics Advanced Higher (4th ed.): Scottish Qualifications Authority.

SQA. (2004d). Physics Intermediate 1: For examinations in and after 2006 Glasgow: Scottish Qualifications Authority.

SQA. (2004e). Standard Grade Revised Arrangements in Physics: General and Credit Levels in and after 2006 Glasgow: Scottish Qualifications Authority.

Stocklmayer, S. M., \& Treagust, D. F. (1996). Images of electricity: How do novices and experts model electric current? International Journal of Science Education, 18(2), 163-178.

Van Driel, J. H. (2010). Model-based development of science teachers' Pedagogical Content Knowledge. Paper presented at the International Seminar, Professional Reflections, International Seminar, Professional Reflections.

https://www.sciencelearningcentres.org.uk/research-and-impact/researchseminars/NSLC\%20UYSEG\%20seminar\%20van\%20Driel.pdf

Van Driel, J. H., Beijaard, D., \& Verloop, N. (2001). Professional development and reform in science education: The role of teachers' practical knowledge. Journal of Research in Science Teaching, 38(2), 137-158. doi: 10.1002/1098-2736(200102)38:2<137::aid-tea1001>3.0.co;2$\mathrm{u}$

Verloop, N., van Driel, J. H., \& Meijer, P. (2001). Teacher knowledge and the knowledge base of teaching International Journal of Educational Research, 35(5), 441-461.

White, R., \& Gunstone, R. (1992). Probing Understanding. London: Falmer Press.

Yin, R. K. (2009). Case Study Research: Design and Methods (4th ed.). Thousand Oaks, CA: Sage. 


\section{Appendix 1 Interview Schedule about Teaching Electricity}

Questions asked in Interviews 1, 2, 3 and 4

Question 1a Quite often a sequence of experiments in first year is start off two cells and then to add one bulb, two bulbs and three bulbs in series. The pupils are going to observer that the bulbs get duller. How would you use these observations to help the pupils?

Question 1b Quite often what pupils will say to you is, "We notice that these two light bulbs are the same brightness and that they are dimmer than the first one." How would your explanation deal with that observation?

Question 1c Why did you decide to use this explanation?

Question 2 The second set of diagrams is a similar experiment, where this time the pupils start off with one bulb and then they add one cell, two cells and three cells in series. The pupils will observe that the bulb gets brighter. How would you start to explain that?

Question 3a After considering series circuits, now we are going to look at parallel circuits. In an ideal world when pupils do this experiment, they find that the bulbs in these circuits are equally bright. How would you explain this observation?

Question 3b Quite often what happens in schools after introducing series and parallel circuits practically, pupils are asked to look at circuit diagrams and to compare the brightness of the bulbs in the diagrams. How would you like pupils to think through this example?

Question 3c How would you like pupils to think through an even more complicated example?

Question 4 What I'd like to do now is to talk about a bit about teaching electricity in third and fourth year. The pupils study series and parallel circuits but more mathematically. How would you expect pupils to calculate the missing values in the following circuits?

4a Two resistors in series;

4b Two resistors in parallel;

4c Two resistors in parallel in series with a resistor;

4d A more difficult example from the Higher Physics syllabus with the question $4 \mathrm{c}$ in series with a fourth resistor.

Question 5 deals with the introduction of potential divider circuits.

5a How would you introduce students to a simple potential divider circuit?

5b How would you like pupils to think through a potential divider circuit with a resistor and a variable resistor?

5c How would you like pupils to think through a potential divider circuit with a resistor and an LDR (light dependent resistor? 
5d A more difficult example from the Higher Physics syllabus has two resistors in series with an LDR. The pupils were told that when light shines on the LDR its resistance goes down. Qualitatively, what happens to the voltages across the three resistors when the circuit is in the dark?

Question 6 The last set of questions are more general.

6a What do you think are the important ideas to get across when teaching electricity?

6b In your experience up to now, what problems do you think pupils have with electricity?

6c The last question is: do you have any other points you would like to make?

Preliminary questions for Interview 2

Question 7a What experience did you have teaching electricity on placement?

Question 7b Do remember much about how you were taught electricity yourself as a pupil?

Question 7c Do you think that your ideas about teaching electricity have changed as a result of being in school?

Preliminary question for Interviews 3 and 4

Question 8a What do you think are the important things to get across when teaching electricity?

Question 8b Do you think your ideas about teaching electricity have changed? 